\title{
A STUDY ON CUSTOMER PERCEPTION TOWARDS LIFE INSURANCE CORPORATION OF INDIA (WITH SPECIAL REFERENCE TO KUMBAKONAM TOWN)
}

\author{
Dr. T. UNNAMALAI ${ }^{1}$, V. RAJINIKANTH ${ }^{2}$ \\ 1 Head \& Assistant Professor, \\ DEPARTMENT OF COMMERCE, \\ BHARATHIDASAN UNIVERSITY CONSTITUENT ARTS AND SCIENCE COLLEGE \\ NAVALURKUTTAPATTU,SRIRANGAM,TRICHIRAPALLI. \\ 2 RESEARCH SCHOLAR, \\ BHARATHIDASAN UNIVERSITY CONSTITUENT ARTS AND SCIENCE COLLEGE \\ NAVALURKUTTAPATTU,SRIRANGAM,TRICHIRAPALLI.
}

\begin{abstract}
This study shows at how consumers feel towards life insurance companies in Kumbakonam. Since people are becoming more aware of their own mortality and the insurance industry is becoming more competitive, it is important for insurance providers to consider their customers' needs. The primary goal of this research is to determine customer satisfaction with LIC. This research is based on primary data collected via a questionnaire from 150 policyholders in Kumbakonam, and the data was analysed using percentages and the chi-square test to determine the factors that influence customer satisfaction with LIC.
\end{abstract}

Key Words: Awareness, Satisfaction, Policyholders, LIC

\section{INTRODUCTION}

One of the most significant segments of the economic sector is insurance. Insurance is characterized as a cooperative mechanism for spreading the loss caused by a specific risk among a group of people who are exposed to it and agree to insure themselves against it. It is a pledge to perform in the future in exchange for a monetary payment now. Such a commitment is made in a situation where the consumer has no way of knowing whether or not the promise will be kept if and when the need arises. In India, LIC provides a wide and diverse range of products to meet the needs of different segments of the population. It provides customized strategies based on their unique financial needs and risk profile, so the LIC is focused on their customers and their satisfaction after purchasing a policy.

Customer satisfaction isn't a figment of the imagination in the insurance industry. While insurance marketers have regarded the "customer" as king and evolved all practices to please him or her, in order to give this concept traction, it is important to understand the client's satisfaction with various aspects and attributes of service. Customer satisfaction is measured by customer loyalty, retention, repurchase intention, and business success. A service, unlike a product, may have a variety of intangible or qualitative requirements. This report, which is based on the aforementioned construct, aims to investigate policyholders' (customers') expectations and satisfaction with the various services provided by life insurance companies in Kumbakonam.

\section{IMPORTANCE OF THE RESEARCH}

Consumer satisfaction is one of the most valuable resources for any insurance provider, and it focuses on analysing the customer's level of awareness and satisfaction with their risk-free investment. As a result, it's critical to look for factors that affect consumer loyalty and lead to the growth of our economy. Aside from that, it's important to figure out what's keeping you from being a life insurance client. It is a unique viewpoint in comparison to studies performed based on variables such as regulations, price, and promotion, and it will aid in improving the life insurance corporation's ability to provide good policies to their customers based on their needs. 


\section{STATEMENT OF THE PROBLEM}

\begin{abstract}
The study looked at LIC policyholders' customer understanding and satisfaction levels. Consumers are more concerned about their satisfaction and a more dynamic and ruthless market has caused policyholders to become more knowledgeable about the policies they have purchased. In the insurance sector, customer loyalty is a crucial weapon. A change in the customer's taste and preferences Customers' expectations should be identified and prioritised by LIC so that the organisation can implement a modern markets environment to prevent mistakes and offer more services to its customers. As a result, the LIC business must understand which aspects to calculate and define the various tools for satisfying and maintaining customers in order to achieve longterm benefit.
\end{abstract}

\section{OBJECTIVES OF THE STUDY}

The objectives of the studies as follows as

- To determine the factors that influence consumer loyalty in the life insurance industry.

- To assess the reasons given by policyholders for purchasing a life insurance policy.

- To determine the level of satisfaction of life insurance customers with the insurer's services.

- To investigate how customers feel about LIC's after-sales operation.

\section{METHODOLOGY}

For the purpose of analysing consumer satisfaction with life insurance companies, a descriptive research design was used. This research is focused on both primary and secondary sources of information. Questionnaires were used to obtain primary data. The first section of the questionnaire contains the consumer's demographic profile, while the second section contains five-point scale questions about customer satisfaction with Life Insurance Company. The sample size was set at 150 people, and data was collected using simple random sampling techniques. Using appropriate methods such as percentage analysis and the chi-square test. The results of the collected data were analysed, and the findings were interpreted.

\section{REVIEW OF LITERATURE}

It emphasizes the observations of a previous report on customer satisfaction and the life insurance corporation. The previous study aids in gaining an understanding of the various approaches taken by previous researches in the area, as well as identifying research gaps. The following are a few excerpts from the work of a well-known author.

G. T. Sharma (2010), It reaffirms the need to adapt Western research techniques for assessing service quality attributes to the sense of Indian life insurance. The study also found that customer satisfaction with agents, practical services, and the organisation is influenced by service quality dimensions, which has an effect on overall satisfaction. While this study focuses on the life insurance industry in India, the findings and recommendations in this article can be applied to increase service quality and, as a result, customer satisfaction in other countries' life insurance industries.

According to insurers, Farokhian.S.,Vazifehdus.H.,(2013), has clarified the factors affecting the insurance industry. Customer satisfaction and other measures and factors in the performance of insurance companies were described in the first report, which used the Servqual model (service quality factors). Finally, the most important factors were identified as access, customer response time, and confidence in customer satisfaction, and the most significant metrics of performance in the insurance industry were identified as knowing the customer, credit, insurance, and customer relationship.

Kuhlemeyer, A. G., and Allen, H.G., (2014) investigate customer satisfaction in the purchase of life insurance products and compare satisfaction in a broker or agent aided transaction to satisfaction in a direct placement transaction without the use of a broker or agent. Consumer satisfaction with the life insurance policy, the provider, and the institution are all measured against benchmarks. Consumer satisfaction is influenced by factors such as confidence, competence, and product appropriateness, according to the report.

Subashini R. (2016) examined that service quality and customer satisfaction in banks can be explored further to determine what approach banks use for different service quality and customer satisfaction over a sample period. Despite the fact that a number of studies have discovered inconsistencies in service quality and customer satisfaction and have attributed various 
explanations for service quality and customer satisfaction of foreign and public banks, no study has been able to resolve this problem.

Dr.T.Unnamalai (2018) has anlalysed the customer satisfaction and customer awareness about service rendered by the Life insurance corporation. Life insurance corporation of India competes other plays in the market very aggressively with their human resource of agents because the police holders are having more faith with agents.

\section{RESULTS AND DISCUSSIONS}

The study's findings shed light on customer satisfaction with life insurance Corporation in Kumbakonam, highlighting customer satisfaction, perception, and attitude toward the insurance industry.

Table -1 Reason for purchase of Insurance Policy (Rank analysis)

\begin{tabular}{|c|c|c|c|}
\hline Reason & Frequency & Percentage & Rank \\
\hline Investing for future & 45 & 28 & IV \\
\hline Well known agent & 60 & 39 & I \\
\hline Prompt service & 25 & 16 & VII \\
\hline Recommendations from friends & 36 & 23 & V \\
\hline Easy accessible & 22 & 14 & VIII \\
\hline Coverage of Risk & 28 & 18 & VI \\
\hline Savings & 46 & 30 & III \\
\hline For the purpose of Taxation & 50 & 32 & II \\
\hline Self interest & 44 & 28 & VI \\
\hline
\end{tabular}

Source: Primary Data

The above table-1 demonstrates that knowing an agent is a very important reason to buy a policy, that saving and tax purposes are also important reasons to buy a policy, and that simple usability is the least important reason to buy a policy

Table - 2 Satisfaction about the services of LIC

\begin{tabular}{|l|l|l|l|l|l|l|}
\hline Statement & $\begin{array}{l}\text { Highly } \\
\text { satisfied }\end{array}$ & Satisfied & Neutral & Dissatisfied & $\begin{array}{l}\text { Highly } \\
\text { dissatisfied }\end{array}$ & Mean \\
\hline $\begin{array}{l}\text { The agent's encouragement to purchase } \\
\text { the policy }\end{array}$ & 30 & 74 & 41 & 5 & 0 & 2.01 \\
\hline $\begin{array}{l}\text { Advice/assistance at the time of policy } \\
\text { purchase }\end{array}$ & 29 & 91 & 23 & 6 & 1 & 2.00 \\
\hline Consistency in releasing policies & 29 & 74 & 39 & 7 & 1 & 2.10 \\
\hline $\begin{array}{l}\text { Contact by agents after issuing the } \\
\text { policy }\end{array}$ & 23 & 69 & 43 & 13 & 2 & 2.20 \\
\hline Renewal notices are sent out on time & 24 & 69 & 43 & 13 & 2 & 2.30 \\
\hline
\end{tabular}




\begin{tabular}{|l|l|l|l|l|l|l|}
\hline $\begin{array}{l}\text { company's attitude toward issuing } \\
\text { loans secured by insurance policies }\end{array}$ & 14 & 69 & 54 & 11 & 2 & 2.35 \\
\hline $\begin{array}{l}\text { Loan process and interest rates for } \\
\text { policy holders }\end{array}$ & 24 & 54 & 53 & 14 & 5 & 2.46 \\
\hline
\end{tabular}

Source: Primary Data

It is evident from the above table-2 that loan process and interest rates for policy holder is most significant factor for customer satisfaction with highest mean of 2.46 , followed by company's attitude towards issuing loans secured by insurance policy with mean 2.35 and Renewal notices are sent out on time for policy with 2.3 mean where as Advice/assistance at the time of policy purchase is the least important factor in customer satisfaction towards LIC services

\section{Table - 3 Chi-Square test- Consumer satisfaction on their Gender}

H0: Respondents' satisfaction does not differ substantially based on their gender.

H1: Respondents' satisfaction does differ substantially based on their gender.

\begin{tabular}{|c|c|c|c|}
\hline \multirow{2}{*}{ Level of Satisfaction } & \multicolumn{2}{|c|}{ Gender } & \multirow{2}{*}{ Total } \\
\hline & Male & Female & \\
\hline Highly satisfied & 30 & 25 & 55 \\
\hline Satisfied & 29 & 15 & 44 \\
\hline Neutral & 20 & 12 & 32 \\
\hline Dissatisfied & 05 & 05 & 10 \\
\hline Highly dissatisfied & 06 & 03 & 09 \\
\hline Total & 90 & 60 & 150 \\
\hline \multicolumn{3}{|c|}{ Calculate Value (Chi-Square Test) } & 1.9886 \\
\hline \multicolumn{3}{|l|}{ Table Value } & $2.447(5 \%)$ \\
\hline \multicolumn{3}{|l|}{ Degree of Freedom } & 5 \\
\hline
\end{tabular}

Source: Primary Data

The above table- 3 shows that Males account for 30 of the 55 extremely satisfied respondents, while females account for 25. The Life Insurance services have been rated as satisfactory by 99 people. Males account for 59 of the 99 policyholders.

The Chi-square test calculated value is 1.9886 and the table value is 2.447 at the degree of freedom 5. In the above-obtained result, since the table value is more than the calculated value so the null hypothesis is accepted and the alternate hypothesis is rejected. Hence it concluded that Respondents' satisfaction does not differ substantially based on their gender.

\section{SUGGESTION AND CONCLUSIONS}

Despite the high level of competition in the market, the study shows that the general public sector LIC dominates the Indian insurance industry. In today's dynamic environment, customer loyalty has become a critical factor in retaining customers through enticing offerings and top-notch facilities. Firms like satisfied and highly profitable consumers due to increased competition, a large array of policies and product products, and a variety of distribution channels.

The study also reveals that almost all of the respondents are aware of the Life Insurance Corporation of India. Approximately 56 percent of respondents bought life insurance on their own 
volition because they need a sense of uncertainty. Furthermore, it was discovered that 81 percent of respondents think being a policyholder in LIC is a good thing. 19 percent of the survey respondents agree that they are unhappy with this insurance service provider and intend to switch in the future.

\section{Reference}

Siddiqui, H.M. Sharma, G.T., (2010), "Analysing customer satisfaction with service quality in Life insurance services", Journal of Targeting Measurement and analysis for marketing 18, 221-28.

Farokhian. S., Vazifehdus, H., (2013), "Factors influencing customer satisfaction with success factors identified in the insurance industry", ISSN 19938233, Academic Journals Vol.7(21)., pp.2026-2032.

Kuhlemeyer, A.G. Allen, H.G.,(2014), “Consumer Satisfaction with Life insurance: A bendmarking survey", Journal of Financial Counseling and planning.

Subashini R., (2016), “A review of service quality and customer satisfaction in banking services: Global Scenario", Journal of Internet banking and Commerce, 21, S5.

Dr.T.Unnamalai and V. Rajinikanth, (Jan-2018) Customer Satisfaction and awareness on Life insurance Corporation of India (with special reference to Thanjavur District), Pg: 198-205, IJECR.

Dr.T. Unnamalai and V.Rajinikanth, (Jan-2019), Measuring Customer Satisfaction Towards Products of LIC with special reference to Kumbakonam Town. Pg:14-19,IJRAR. 